\title{
Decentralization of Ukraine Spells New Challenges to Canonical Orthodoxy
}

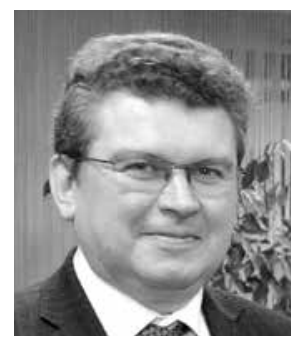

Vladislav I. Petrushko, Doctor of Church History, is Professor at St. Tikhon Orthodox Humanitarian University. Interviewed by Alexander V. Solovyov.

$10.31278 / 1810-6374-2018-16-2-194-203$

- How would you describe the current developments in Ukraine's Orthodox world?

- They are a direct projection of what is happening in the country's politics. To a certain extent, this is a logical result of the 25-year-old project called "Ukraine," which has been developing in accordance with the principle President Leonid Kuchma postulated in the title of his book Ukraine Is Different from Russia. This idea eventually put the majority of Ukraine's population in an abnormal position. Corresponding problems emerged in church affairs. The canonical Ukrainian Orthodox Church, which is part of the Moscow Patriarchate, on the one hand exists in accordance with the Russian Orthodoxy paradigm, but on the other, it has found itself amid the realities of a Ukraine that is "different from Russia," inside a state hostile towards Russia. The new authorities see the Ukrainian Orthodox Church as an organization whose spiritual center is connected with what they regard as an "aggressor country." Obviously, the canonical Ukrainian Church will continue to be viewed in this way as long as the current authorities stay in power. Accordingly, government officials will remain negative towards the church and will try to drive a wedge between it and the Moscow Patriarchate. 
An autocephalic status will not help, because a large share of believers in eastern Ukraine are accustomed to the traditional format of Orthodoxy, which took shape within the Russian church tradition. Many parishes would refuse to accept the jurisdiction of an autocephalic church if it should appear someday. Another schism in Ukrainian Orthodoxy would follow.

\section{- But the external factor-the political one-is complemented by the internal, purely church factor, isn't it?}

- The problem is not confined to the negative attitude of the Ukrainian authorities towards the canonical Church alone. There is the so-called Kiev Patriarchate, which has existed for quite a long time, and even if autocephaly does eventually materialize, something will have to be done about that institution. Next there is the problem of ambitious leaders, like Filaret and his followers who share his stance: Constantinople or Moscow makes no difference. The Kiev Patriarchate project was not launched to get under some other jurisdiction as a dependent structure. The Ukrainian Greco-Catholic (or Uniate) Church is another major player. It positions itself as Orthodox from the standpoint of tradition and Catholic in terms of the format of its relations with Rome. Since the mid-twentieth century its aim has been to pool all of Ukraine's Orthodox and Greco-Catholic traditions into one patriarchate- under the aegis of the Pope, of course. The Uniate Church by virtue of its Galician origin proclaims itself as the most patriotic church and the most adequate for the ideals of an independent Ukraine. The Uniates have been pushing towards the East and the South very aggressively by creating exarchates there. It is not accidental that their main (patriarchal, as they say) cathedral was built in Kiev on the left bank of the Dnieper, as a symbol of their claim to the territories on the left bank of the Dnieper, which they have "staked out" for their mission.

In this complex situation, the future of Ukrainian Orthodoxy largely depends on the personality of the primates. The Ukrainian Orthodox Church of the Moscow Patriarchate today is led by Metropolitan Onufriy, a hierarch of tremendous spiritual authority, 
a truly ascetic monk and a person of principle. On the one hand, this is the great strength of Ukrainian Orthodoxy, a spiritual pillar it rests upon. But on the other hand, we know that an inability to compromise always breeds problems. We all remember the moment when Metropolitan Onufriy, as one of Ukraine's top officials, refused to stand for a moment of silence for the heroes of the so-called antiterrorist operation (ATO), as he believes - quite reasonably - that there can be no heroes in a civil war. Naturally, a stance like this is a great annoyance for the Ukrainian authorities and puts pressure both on the primate and the Church.

\section{- What is the role of the Ecumenical Patriarchate in Constanti-} nople in this situation? Does it manifest itself somehow, conspicuously or inconspicuously?

- It all depends on what the adjective "inconspicuous" applies to. For instance, just recently the Patriarchate in Constantinople declared that it was planning to establish a dependency in Kiev and Lvov. As far as I know, nobody has tried to coordinate this with the Moscow Patriarchate or the Kiev diocese. In the same fashion, without notifying Bishop Ieronymos of Athens, Patriarch Bartholomew opened his dependency in Athens. Generally speaking, the Ecumenical Patriarchate has made it clear repeatedly that it sees Ukraine as its canonical territory. Last year, Patriarch Bartholomew, in his message on the Holodomor in Ukraine, for the first time referred to Ukrainians as a flock of the Ecumenical Patriarchate, which, he wrote, had suffered from genocide. In other words, Constantinople repeatedly calls into question the transfer of the Kiev diocese to the Moscow Patriarchate in the 1680s. The arguments vary, but Constantinople regularly and inconspicuously, as you say, presses for the idea that Ukraine is its canonical territory. At a certain point, particularly dramatic for the Ukrainian Orthodox Church, Constantinople may embark on a far more proactive policy along these lines.

For now, I believe Constantinople is still reserved because it is reluctant to trigger a scandal of global proportions in the Orthodox world-such actions would be fraught with the complete severing 
of relations with the Moscow Patriarchate. Secondly, a considerable share of believers and clergy of the Ukrainian Orthodox Church are determined even in the current situation to retain canonical unity with the Russian Orthodox Church. I reckon that the election of Metropolitan Onufriy was a clear sign that even though some bishops are nationalistically minded, in a situation where the smell of gunpowder is in the air, the choice was made in favor of Onufriy as a hierarch of the greatest authority, despite his outspoken "pro-Moscow stance" (not political, of course, but in the sense of preserving church unity).

Constantinople, too, can feel that the Ukrainian Orthodox Church is far from the spirit of Hellenism, so common in Greek churches, where their own nationalist aspect is present, too, and where the situation is rather peculiar. Constantinople is keen to gain footholds in many places and to pique the Moscow Patriarchate, but I believe it is well aware that Ukraine's religious annexation would be beyond its powers. Phanar's losses from such a move would by far outweigh any gains.

- And what kind of response does Constantinople's keen interest in Ukraine draw from Ukraine's other confessions that position themselves as Orthodox? Are they critical or do they tend to display greater understanding towards the Ecumenical Patriarchate?

- The so-called Ukrainian Autocephalous Orthodox Church has tight bonds with Constantinople. At a certain point they looked prepared to accept Constantinople's jurisdiction. At least they mentioned the Metropolitan of the Constantinople jurisdiction, the head of the Ukrainian Orthodox Church in the U.S. After the death of so-called "patriarch" Dimitry Jarema, they refrained from electing a new "patriarch." The primacy of the metropolitan looked like it was enough. The influence of the Ukrainian Autocephalous Church in Ukraine today is not very large. In fact, it is a marginal community... Moreover, the UAOC, in contrast to the "Kiev Patriarchate," does not meddle in politics. The UAOC is not the material Constantinople might find useful to construct its own jurisdiction in Ukraine. As for 


\section{Vladislav I. Petrushko}

the "Kiev Patriarchate," the ambitions of its primate, Filaret, as they are, he will refuse to repent to anyone under any circumstance. He wishes to remain the "patriarch," so his contacts with Constantinople will be rather hard to establish, because full-fledged church relations with Phanar for him would be possible on the basis of repentance and adoption into Constantinople's jurisdiction as a metropolitan, and not a patriarch. Over the past quarter of a century Filaret has gotten used to his current status and, although the Orthodox world has not recognized it to this day, is totally unprepared to agree to this option.

- And to what extent does an Orthodox Christian in Ukraine-a Ukrainian or Russian-belong (or not belong) to the Russian World?

- It is difficult to say unequivocally. Although a high degree of religiousness is a characteristic feature of the Ukrainians, I would not exaggerate it. The Ukrainian mentality, and Ukrainian culture on the whole, is rural and folkloric, so Ukrainian religiousness is very close to the rural type. This explains why many Ukrainians attach so much importance to the outward manifestations of churchliness and rituals, in some cases coming pretty close to faith in rituals. For such people the term 'Russian World' hardly plays any significant role. As far as churched intellectuals are concerned, their attitude towards the Russian World depends on the current polarization of Ukrainian society. For the champions of "Maidan ideals" the term "Russian World' is strongly hostile. As the Maidan protests and ensuing events have shown, in recent years Ukraine has seen the emergence of a Russian language form of Ukrainian nationalism-very different from traditional Galician Russophobia. And yet quite a few people in Ukraine remain committed to pro-Russian positions, to the unity of the Russian people, if you wish. For them the idea of the Russian World remains as important as before. Gauging this in quantitative terms would be quite difficult.

For some, the idea of an independent Ukraine might be of some value not as "anti-Russia," but as an alternative, legitimate way of development for the Russian World to follow. Therefore, the latest events, mainly Crimea's return to the Russian fold, drew quite a painful 
reaction from many people in Ukraine, even from those who are proRussia-minded. Possibly, Ukraine will still to go through many trials before its people are able to take a sober look at what happened.

\section{- And how does Orthodoxy in Ukraine react to the war in}

\section{Donbass?}

- In different ways. It all depends on the regions. The farther to the west, the more often we hear stories of how even entire parishes of the Moscow Patriarchate are launching campaigns to raise money and aid for the Ukrainian army. Indeed, it is quite a demonstration of loyalty to the authorities and the wish to show "We are not a fifth column." It is also true that the farther west you go, nationalist sentiment grows stronger, even in the affairs of the canonical Church. As far as I know, in the territory controlled by the Donetsk and Lugansk selfproclaimed republics, the clergy mostly agree with the stance of their authorities and feel the same way as the public at large. I believe that in neighboring territories under Kiev's control (the Kharkov and Zaporozhye regions and some others), similar sentiment is present, too. The public does not openly express such sentiment very often, of course, because they would be quickly punished. Cases in which priests were arrested on the mere suspicion of supporting "separatism" are too numerous to count. But such sympathy is a projection of the way ordinary people feel. We understand well enough that first and foremost it is not "Russian aggression," but the refusal of people in these territories to accept the regime and the ideology that Maidan has brought with it, thus triggering the Donbass events.

- As far as I can judge, the parties to the conflict are irreconcilable and see no outlook for compromise. The sole point of agreement between them is that there is nothing for them to agree on by and large. What is the attitude of the Orthodox Church to this? Will it try to take some conciliatory moves or confine itself to preaching? Or does that make any sense, too?

- The Canonical Ukrainian Orthodox Church and its head are the sole force in Ukraine capable of taking a proper look at the current 
events precisely as a civil war. The irreconcilability of all others is the clearest evidence that it is a civil standoff, a civil war. Metropolitan Onufriy's refusal to remember so-called ATO heroes was an expression of the idea the ongoing events are a problem that exploded Ukrainian society from within, and not as a confrontation between Ukraine and Russia. This stance has brought about real action-it was the Ukrainian Orthodox Church that initiated the recent exchange of prisoners of war. Patriarch Kirill provided great assistance. In general, the Ukrainian Orthodox Church believes that its flock is on both sides of the frontline and is behaving accordingly. It is not accidental that these territories-just as Crimea-remain under the jurisdiction of the Ukrainian Orthodox Church. This is fair and reasonable. It is the last opportunity for keeping this space together with the spark of Christian love amid the ongoing nightmare. The exchange of prisoners was a great achievement. Hopefully, more will follow.

\section{- How great is the risk that Ukraine's central authorities} may decide that the Ukrainian Orthodox Church of the Moscow Patriarchate is hopelessly disloyal and outlaw it in the country's territory?

- If the Ukrainian authorities are still in their right mind, they would never dare make such a move. At the very least because an overwhelming majority of Ukrainian believers belong to the canonical Ukrainian Orthodox Church. Even the Catholic monarchs of the Grand Duchy of Livonia, where Orthodox Rusyns accounted for 90 percent of the population, never went as far as outright attempts to do without Orthodoxy. Under the Mongols, however brutal they might have been, any act of animadversion towards the faith of any of the Mongol Empire's peoples was punishable by death. On the one hand, it was a manifestation of tolerance typical of pagans. On the other, a result of a reasonable awareness that people quite often may put up with various hardships (such as Ukraine's soaring utility prices and shortages of natural gas), but should their religious feelings be affected - a wave of anger and protests may rise high and sweep away everything. 
Something makes me feel that nothing like this will happen. Yet the risk should not be ruled out completely because the current authorities in Ukraine occasionally act in a suicidal manner. Which merely confirms that power is in the hands of people who are utterly dependent and incapable of conducting a sensible policy of their own, but who simply follow orders from those who are totally indifferent about Ukraine's future.

- Should we expect heated debates in the context of Orthodox historical memory, which may drift into totally irrational fields? Won't some say that the center of Russian Orthodoxy should be moved to Kiev? That the city should be restored to that role? After all, historically Kiev was the center of Orthodoxy in Russia in the old days...

- Such speculations sound far-fetched. It's true that all of us respect our history and our antiquities, but they cannot be literally followed in the modern context. If it were otherwise, the Church of Antioch, for instance, should be pressing for the return of its historical center to Antioch, in the territory of modern Turkey... I can think of other examples too. Meanwhile, the mainstream trend of Russian Orthodoxy was taking shape in northeastern Rus' starting in the thirteenth century. Batu Khan's invasion ruined Kiev. The metropolitans first moved to Vladimir and then to Moscow... Even Orthodoxy in Western Russia in later periods was not linked to Kiev very tightly. Kiev's metropolitans in the fifteenth and sixteenth centuries lived in Novogrudka or Vilna. It goes without saying that Kiev has always been regarded as a holy shrine in ancient Rus', as its spiritual symbol. But that does not necessarily mean that the center of the Russian Church has to be there now.

The specific traits of the Russian Orthodox Church in the Middle Ages result from the fact that it existed in the territory of the only Orthodox state at that moment in time-the state of Moscow. Naturally, that left the decisive imprint. The Moscow Patriarchate emerged as a parallel to the royal dignity of the Russian tsars. And this far longer period and far more important one from the standpoint of 
the emergence of the local Russian church tradition is an undeniable fact. We should proceed from the realities, and not hypothetical speculations. Historian Vasily Bolotov said "everything that benefits the Church is canonical." If it turns out beneficial for the Church to have its spiritual center in Kiev-under certain circumstances someday-then thank Heaven! But it would be very wrong to resort to far-fetched arguments by recalling that our Orthodoxy began in Kiev with a baptism in the Dnieper. The more so, since this question cannot be relevant today, when power in Kiev belongs to Orthodoxy's arch foes and russophobes.

- Is it correct to say that canonical Orthodoxy in Ukraine will remain under pressure from current politics and that pressure will be two- or even three-fold: firstly, internal, due to Ukraine's own split caused by the civil war; secondly, external, induced by the activity of non-canonical confessions inside Ukraine; and thirdly, from the Ecumenical Patriarchate in Constantinople?

- Yes, certainly. Also, I would add that sooner or later, in several years from now or at a much later date, Ukraine will be forced to start along the route of federalization. Its decentralization is inevitable. Keeping the East, traditionally and spiritually close to Russia, and ultra-nationalist West in one vessel will be impossible. The entire historical experience of the twentieth century demonstrated that this does not work. In all likelihood, regions will gain greater independence and Ukrainian Orthodoxy will transform accordingly. The way I see it, Constantinople's intervention, if it does take place, will most probably be focused on the western regions, where it will try to establish its jurisdiction.

- Will federalization have an overall favorable effect on Orthodoxy in Ukraine or will it bring about more challenges and problems?

- More challenges are due. While for the dioceses in the eastern and southern regions it would be a more favorable outcome, the autonomization of the West will not only preserve power in the hands of 
the current authorities, but also trigger some exaggerated trends, up to the declaration of Uniatism as a state religion. Naturally, for Orthodox Christians in Western Ukraine this may spell more problems.

- And how might the Orthodox Church respond to the declaration of Uniatism as a state religion? It will have to formulate some official policy and maintain some official contacts.

- It is hard for me to say right away. Firstly, in the West, in Galicia, approximately two-thirds of the population are Greco-Catholics, onethird regard themselves as Orthodox, but an overwhelming majority of them belong to breakaway confessions-the Kiev Patriarchate and the Ukrainian Autocephalous Orthodox Church. In Volyn, the situation is somewhat different. Canonical Orthodoxy there is in a slightly more favorable position. But the hypothetical autonomization of Western Ukraine will provide Constantinople with a real opportunity to step in by providing assistance to those discriminated against and by offering the services of a go-between in disputes. The Greeks have vast experience of this sort, regrettably. I foresee a potential sore spot here that may make itself felt with the passage of time. 